можливості знань як путівника до максимально повної самореалізації в житті; знань як можливості досягнення мети життя; знань як можливість набуття свого призначення.

Ключові слова: підготовче відділення університеmу, абітурієнти, лінія Платона, знання як спосіб життя, менеджмент

Цель. Раскрыть особенности управления подготовительным отделением университета в философской традиции Платона, согласно которой получение знаний рассматривается как способ жизни. Авторы акцентируют внимание на: 1) частоте обновляемости потоков учащихся; 2) гибридизации образования в перспективе глобальной трансформации образования; 3) необходимости адаптации абитуриентов к высшей школе.

Методика. Авторы использовали диалектический метод, системно-структурный, структурно-функциональный, а также методы: сравнения, анализа, синтеза, экспертной оценки.

Результаты. Предложено организовать управление подготовительным отделением университета в философской традиции линии Платона, которая позволяет абитуриентам рассматривать знания как способ жизни, а не как услугу. Авторы выделили и рас-

UDC 330.101.541:330.341

S. V. Lyeonov, Dr. Sc. (Econ.), Prof., orcid.org/0000-0001-5639-3008,

T. A. Vasylieva, Dr. Sc. (Econ.), Prof., orcid.org/0000-0001-7889-3521,

O. V. Lyulyov, Cand. Sc. (Econ.), Assoc. Prof., orcid.org/0000-0002-4865-7306 смотрели в управлении подготовительным отделением университета три основные особенности, которые в настоящее время требуют особого внимания: 1) частота обновляемости потоков учащихся; 2) гибридизация образования в перспективе глобальной трансформации образования; 3) необходимость адаптации абитуриентов к высшей школе. Предложены авторские решения вышеназванных задач.

Научная новизна. Разработана стратегия управления подготовительным отделением университета в философской традиции линии Платона, которая позволяет абитуриентам рассматривать знания как способ жизни, а не как платную услугу.

Практическая значимость. Использование полученных результатов в образовательной практике позволяет раскрыть возможности знаний как путеводителя к максимально полной самореализации в жизни; знаний как возможности достижения цели жизни; знаний как возможности обретения предназначения.

Ключевые слова: подготовительное отделение университета, абитуриенты, линия Платона, знания как способ жизни, менеджмент

Рекомендовано до публікації докт. філос. наук Г.С. Аляєвим. Дата надходження рукопису 14.12.16.

DOI: $10.29202 /$ nvngu/2018-1/4

Sumy State University, Sumy, Ukraine, e-mail: s.leonov@uabs. sumdu.edu.ua; tavasilyeva@fem.sumdu.edu.ua; alex_lyulev@ econ.sumdu.edu.ua

\title{
MACROECONOMIC STABILITY EVALUATION IN COUNTRIES OF LOWER-MIDDLE INCOME ECONOMIES
}

\author{
С. В.Лєонов, д-р екон. наук, проф., \\ orcid.org/0000-0001-5639-3008, \\ Т. А. Васильєва, д-р екон. наук, проф., \\ orcid.org/0000-0001-7889-3521, \\ О. В. Люльов, канд. екон. наук, доц., \\ orcid.org/0000-0002-4865-7306
}

Сумський державний університет, м. Суми, Україна, e-mail: s.leonov@uabs.sumdu.edu.ua; tavasilyeva@fem.sumdu.edu.ua; alex_lyulev@econ.sumdu.edu.ua

\section{ОЦІНКА МАКРОЕКОНОМІЧНОЇ СТАБІЛЬНОСТІ КРАЇН 3 НИЗЬКИМ І СЕРЕДНІМ РІВНЕМ ДОХОДУ}

Purpose. Developing methods to evaluate macroeconomic stability of countries with lower-middle income economies. The results of analysis will help to make conclusions concerning regulatory economic policy in the given countries to their macroeconomic dynamics level.

Methodology. While investigating macroeconomic stability, the conception of macroeconomic stability pentagon was used which is based on evaluation of five basic macroeconomic indexes: level of GDP growth; unemployment rate; inflation rate; budget balance of the state to GDP; balance of the current turnovers size to GDP. The applied methodic tools are modification of methods, suggested by Professor of Economics Grzegorz W. Kolodko, Dr. Con-

(C) Lyeonov S.V., Vasylieva T.A., Lyulyov O. V., 2018 
stantin Zaman, and Branko Drcelic. It is completed with the authors' ideas to consider break of the standard fluctuations, asymmetry and extreme deviations as dynamic indicators of the economic agents' response to the positive or negative impacts of the macroeconomic destabilization.

Findings. The results of macroeconomic stability pentagons empiric analysis for countries with the lower-middle income economies at different stages of the economic cycle (precrisis period (2000-2006), crisis period (2007-2010) and postcrisis period (2011-2015)) proved the lack of coordination in different economic policies of every studied state. The statistic indicator of the macroeconomic stability is calculated. It is suggested to calculate its dynamic indicator, which differs from statistic one by considering standard fluctuations, asymmetry and extreme deviations of its subindices. It lets to define low syncronization of the analyzed countries' policies, which have to provide the main five directions of the macroeconomic stability.

Originality. The authors propose to calculate the dynamic indicator together with statistic indicator of the macroeconomic stability, that allows:

- taking into account negative tendencies, which can be leveled owing to stabilization of all other subindices;

- analyzing behavior of the economic agents as a response to positive or negative impacts;

- considering the character of distinguishing subindices of the macroeconomic stability integral indicator.

Practical value. The obtained results will allow evaluating the rate of coordination of separate components of the economic policy in the studied states with the purpose of achieving macroeconomic stabilization. It is a ground to investigate scripts to achieve macroeconomic stability taking into account an optimal rate of the main subindices of macroeconomic stability integral indicator, minimization of the standard fluctuations break, asymmetry of extreme deviations.

Keywords: macroeconomic stability, economic growth, competitiveness, economic policy, macroeconomic imbalances, crisis phenomena

Introduction. Increase in the global gross domestic product in 2016 by $2.438 \%$ [1] proves the gradual renewal of the world economy stabilization after the long financial and economic crisis. However, in spite of positive dynamics of the mentioned index in comparison with 2007-2009 (in 2009 it was $1.735 \%$ ), this rate remains lower than global economic growth rate during the pre-crisis period (in 2006 it was $4.326 \%$ ).

Similar tendencies are demonstrated by the global competitiveness index, which is published in the annual Report on global competitiveness by the World economic forum (WEF). Particularly, the highest rate of the global competitiveness index during the post-crisis period was fixed for Switzerland (at the level of 5.81) in 2016. For the crisis period the maximum value was 0.07 points lower (5.74) and was fixed for the United States in 2009. However, the global competitiveness index rate remains much lower ( 0.13 points lower) than the rate, achieved by Finland in 2005 (5.94) [2]. Only 6 EU countries (Finland, Greece, Hungary, Italy, Portugal, Romania) demonstrated negative tendency of the global competitiveness index dynamics in 2016 in comparison with 2015. At the same time, the global competitiveness index gap between European economies was much bigger: in 2016 it was 1.57 points. Particularly, the highest rate of the global competitiveness was in the following countries: the Netherlands (5.57), Germany (5.57), Sweden (5.53), the United Kingdom (5.49), Finland (5.44), and the worst - in Greece (4), which demonstrates tendencies, which are similar to the countries which try to be EU members.

One of the factors, which influence the national economy competitiveness according to the global competitiveness index calculation, is its macroeconomic stability. The Ukrainian rating fall due to the macroeconomic stability for 32 points in 2016-2017 (place 132) in comparison with 2007-2088 (place 100) proves the necessity to introduce an economic policy, oriented to moder- ate the development cycling and economic falls consequences. The ground to realize the proper policy is a scientific substantiation of the balanced driver system and impulses to fasten transformational process.

Analysis of the recent research and publications. Theoretical and applied preconditions of the macroeconomic stability have been comprehensively observed in works of native and foreign scientists. However, lack of the unified terminology concerning the concept of "macroeconomic stability" is one of the reasons why there is no only one decision, accepted by all researchers and specialists, to choose indicators, measuring method and macroeconomic stability rate evaluation.

One of the tools, which can provide the right comparative analysis of the macroeconomic stability rate in different countries, in the context of achieving four main aims in the state policy stabilization (economic growth dynamics, increasing employment, decreasing inflation rate and external balance provision), is a conception of the macroeconomic stability pentagon. It was suggested by the Director of Finances Institute in Warsaw, Professor of Economics Grzegorz W. Kolodko [3]. The mentioned conception was further developed in research of Gheorghe HURDUZEU, Maria-Isadora LAZĂR [4], Dorota Żuchowska [5], Anna Malina, Dorota Mierzwa [3], Jacek Pera [6], Rodica-Oana Ionita [7] and others.

Objectives of the article. The purpose of the article is to develop methods to evaluate macroeconomic stability of countries with lower-middle income economies via the model, which is a modification of the macroeconomic stability pentagon conception, presented by Grzegorz W. Kolodko and the model of Zaman \& Drcelic, added by the authors' proposals to take into account the deviations of real values from standard ones in the country.

Presentation of the main research. The study of Grzegorz W. Kolodko, and scientists, who developed his methodology, is based on analysis of five basic macroeconomic indexes: GDP rate growth (r); unemployment rate 
(U); inflation rate (CPI); balance of the state budget to GDP; balance of the current turnovers to GDP (CA). Every index on the pentagon lines describes the degree of achieving the main macroeconomic objectives by some countries: economic growth; full employment; internal balance (without inflation), balance of state finances and balance of external pays. Degree of these objectives fulfillment is expressed through synthetic index MSP, which measures the surface, defined by peaks of five indexes ratio mentioned above

$$
\begin{gathered}
M S P=a+b+c+d+e= \\
=[(r \times U)+(U \times C P I)+(C P I \times G)+(G \times C A)+ \\
+(C A \times r)] \times k,
\end{gathered}
$$

where $a=r \times U \times k$ is a triangle area, which characterizes the rate of national economy real sector development (the real sphere triangle) as a ratio between GDP growth rate and unemployment rate; $b=U \times C P I \times k$ is $b$ triangle area, which depends on the unemployment rate and inflation rate, and is a stagflation index (the shortageflation (or slumpflation) triangle); $c=C P I \times G \times k$ is $c$ triangle area, which is an indicator of the ratio between the inflation rate and state budget balance; $d=G \times C A \times k$ is $d$ triangle area, which describes the financial balance level (the financial equilibrium triangle) and is calculated as a ratio between the state budget balance and current turnovers size to GDP; $e=C A \times r \times k$ is $e$ triangle area, which describes the rate of the external sector development (external sector triangle), which shows the ratio of current turnovers balance to GDP and GDP growth rate; $k=1 / 2 \sin 72^{\circ}$.

Comparison of the synthetic indicator $M S P$, which measures pentagon surface in particular years allows observing some changes in the countries' development, which occur during the processes of its most important macroeconomic indeces stabilization or destabilization, and to reveal the best experience to realize macroeconomic policy in some countries.

It is well-known that the country's total macroeconomic stability rate is directly-proportional to the pentagon surface area, and at the same time, the balanced state degree of the pentagon form proves the coordination level in the state's regulatory policy separate vectors. In order to provide positive rate of economic growth and economic stability, it is better to support the synthetic indicator $M S P$ at the maximum possible level.

In order to analyze the impact of internal and external factors on macroeconomic stability in more detail, the following equation (1) is given

$$
M S P=M S P 1+M S P 2,
$$

where $M S P 1=a+b+c$ is the indicator which characterizes an impact of external factors on macroeconomic stability of the studied country; $M S P 2=d+e$ is the indicator which describes the external factors' impact on the macroeconomic stability of the studied country.

Detailed analysis of the macroeconomic stability in countries of lower-middle income economies, based on indicators $M S P, M S P 1$ and $M S P 2$, was carried out by us in this work [8].

The main disadvantage of the synthetic indicator MSP analysis is its interpretation specificity. It means that it allows only defining the direction of stabilization processes change and receiving partial information about economic stability rate, based on comparison or with previous period or with data about other country.

In the work [9] another approach is suggested to solve the studied problem, which lets us to distinguish five main levels with the help of macroeconomic stabilization indicator $(I M S)$ :

- IMS € (40;50] - very stable economy;

- IMS € $(30 ; 40]$ - stable economy;

- IMS € $(20 ; 30]$ - medium stable economy;

- IMS € (10;20] - low rate of the stable economy;

- IMS $\leqslant 10$ - extremely unstable economy.

Maximum rate of macroeconomic stability indicator $(I M S)$ can reach 50, and every subindex value, included into pentagon, cannot exceed level 10.

However, the analysis of the macroeconomic stability only due to IMS has statistic character, because it does not consider variation of every constituent element of the $I M S$ indicator and risks to lose their stability. We suppose that macroeconomic stability is necessary to observe, based on two main aspects, particularly:

Firstly, a state, in which balances between the rate and key macroeconomic variables increase, is stable, the macroeconomic variables changeability is within the accepted range, total uncertainty concerning macroeconomic environment is absent.

Secondly, as a process to prevent, to avoid and to liquidate the threats to economic growth with the purpose of satisfying the economic system subjects' increasing needs in conditions of the limited resources.

Measuring of the macroeconomic stability provides for evaluating equilibrium values of variables and their fluctuations from real and control values. Therefore, equilibrium means the existence of constant state or tendency, to which variables come back, as a rule, after deviating. That is why, regarding statistics the evaluation of the macroeconomic stability has to include comparisons of IMS with its component standard deviations [9]. Taking into consideration standard deviations of the variables will allow paying attention to negative tendencies, which can be leveled owing to the achieved stabilization of all other constituents and guarantees that all IMS components have equal volatility, in such a way that changes in index are controlled by the most stable components. At the same time, together with traditional statistical "standard deviation" index, we suggest considering the index of asymmetry or distribution excess degree and an index of extreme deviations appearing. The mentioned indices allow analyzing economic agents' reaction to the positive or negative impacts. Besides, such an approach allows taking into account the character of macroeconomic integral indicator subindices values distribution around trend: 1) it is defined by frequent disturbances in the limited scale; 2 ) rare disturbances prevail in great scales [10].

Thus, mathematic formalization of the mentioned indices calculation provides formula use 


$$
\text { Skewness }_{j}=100 \cdot \frac{\frac{1}{n} \sum_{i=1}^{n}\left(\frac{x_{\mathrm{i}}-\bar{x}}{\bar{x}}\right)^{3}}{\left(\frac{1}{n} \sum_{\mathrm{i}=1}^{\mathrm{n}}\left(\frac{x_{\mathrm{i}}-\bar{x}}{\bar{x}}\right)^{2}\right)^{3 / 2}},
$$

where Skewness is an index of j-component of macroeconomic stabilization indicator (IMS) asymmetry; $x_{i}$ is the value of the proper constituent of macroeconomic stability indicator $(I M S)$ in i-period; $\bar{x}$ is an average value of the proper constituent in macroeconomic stability indicator (IMS) during the analyzed period; $n$ is the number of analyzed periods and

$$
\text { Kurtosis }_{j}=100 \cdot \frac{\frac{1}{n} \sum_{i=1}^{n}\left(\frac{x_{i}-\bar{x}}{\bar{x}}\right)^{4}}{\left(\frac{1}{n} \sum_{i=1}^{n}\left(\frac{x_{i}-\bar{x}}{\bar{x}}\right)^{2}\right)^{2}},
$$

where Kurtosis is an index of extreme deviations appearing of macroeconomic stability indicator $\mathrm{j}$-component (IMS).

The Skewness index close to zero will prove the symmetric distribution of $I M S \mathrm{j}$-constituent, and at the same time, crisis situations impact will reduce or increase it. Thus, no-zero value of the asymmetry index (positive or negative) points the instability, i.e. positive (negative) impacts enduring.

Analysis of the Skewness and Kurtosis indices allows us totally to confirm impact of various unusual fluctuations in the country on IMS constituents. Therefore, in case of symmetric distribution of IMS constituents, the Kurtosis index is equal to 3 or $300 \%$, when it is more or less than the mentioned rate, there is an aptitude of variable to the extreme values.

In order to imagine the macroeconomic stability rate, it is necessary to give a graphic interpretation of the macroeconomic stability pentagon, to compare IMS indicator with the IMS subindices standard deviations sum considering the distinguish asymmetry and extreme deviations appearance.

Explanation of scientific results. In order to approbate the methods, suggested by us, to evaluate macroeconomic stability for the lower-middle income economies of EU countries, IMS values were calculated for time period of 2000-2015 (Table 1). The IMS indicator was calculated taking into account its components normalization via formula

$$
A_{j}=\left(\frac{X_{j}-X_{\min }}{X_{\max }-X_{\min }}\right) \cdot 10,
$$

where $A_{j}$ stands for normalized values of $I M S \mathrm{j}$-subindex; $X_{\max }$ and $X_{\min }$ are maximum and minimum values of the IMS proper subindex:

- variable of GDP rate (g) has a range from 0 to 10 ;

- unemployment rate variable range $(\mathrm{u})$ from 5 to 25 ;

- inflation variable (p) from 0.92 to 4.61 ;

- budget deficit as a percentage of GDP (bd) is from 10 to 2 ;

- foreign deficit/debt (fd) is from 10 to 65.

Analysis of the IMS indicator (Table 1) at different stages of the economic cycle: pre-crisis period (20002006), crisis period (2007-2010) and post-crisis period (2011-2015) demonstrates different speed of macroeco-

Table 1

\begin{tabular}{|c|c|c|c|c|c|c|c|c|c|c|c|c|c|}
\hline & & Ukraine & Latvia & Lithuania & Poland & Croatia & Romania & Bulgaria & Georgia & Moldova & Armenia & Belarus & Serbia \\
\hline \multirow{7}{*}{ 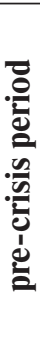 } & 2000 & 29.78 & 26.95 & 29.85 & 26.35 & 20.13 & 24.19 & 22.21 & 24.53 & 22.03 & 25.78 & 32.36 & 22.40 \\
\hline & 2001 & 38.19 & 28.41 & 31.89 & 3.15 & .55 & & & 44 & 55 & & & .66 \\
\hline & 2002 & 38.63 & 0.08 & 34.98 & 80 & 76 & 30.79 & 00 & 40 & 11 & & 16 & 0.04 \\
\hline & 2003 & 41.36 & 30.71 & & 22.69 & 24.00 & & & 31.56 & 30.17 & 10 & 78 & 5.84 \\
\hline & 2004 & 37.94 & 29.28 & 35.21 & 24.98 & 22.96 & 36.37 & 32.25 & 28.86 & 30.06 & & 43 & 28.53 \\
\hline & 2005 & 33.05 & 32. & & & 5 & & & & & & & 44 \\
\hline & 2006 & 33.17 & 34.40 & & 30.78 & 26.10 & & & & & & & \\
\hline \multirow{4}{*}{ 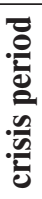 } & 2007 & 29.51 & 33.05 & & 33.38 & 25.46 & 33.09 & & & & & & 23.65 \\
\hline & 2008 & 19.28 & 19.62 & 26 & 29.51 & 25.30 & 32.85 & 32.44 & 22.13 & 32.90 & 33.50 & 76 & 24.77 \\
\hline & 2009 & 0.20 & 13.70 & 21 & 3 & 5 & 66 & 67 & 15.44 & 0 & 13.75 & 61 & \begin{tabular}{|l|}
17.57 \\
\end{tabular} \\
\hline & 2010 & 25.56 & 12.75 & & 23. & 18 & & & 19 & & 09 & & 14.48 \\
\hline \multirow{5}{*}{ 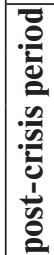 } & 2011 & 23.99 & 24.35 & 26 & 26 & 18 & 23 & & 50 & 71 & 33 & & 14.18 \\
\hline & 2012 & & 26.63 & & & & & & & & & & 9.17 \\
\hline & 2013 & 19.72 & 27.23 & & & 16.38 & & & 25.69 & 34.26 & 61 & & \begin{tabular}{|l|}
17.48 \\
\end{tabular} \\
\hline & 2014 & 19.83 & 25.93 & 28.78 & 26.91 & 17.87 & 29.74 & 23.37 & 27.36 & 30.09 & 22.52 & 95 & 15.69 \\
\hline & 2015 & 17.97 & 26.73 & 27.93 & 28.89 & 19.59 & 31.40 & 27.46 & 24.79 & 22.15 & 20.66 & 25.76 & 19.43 \\
\hline
\end{tabular}

The IMS index for the lower-middle income economies countries for time period of 2000-2015 (the authors' own calculations based on Eurostat data [1]) 
nomic stability changes of national economies in the studied countries. During the pre-crisis period most countries, except Croatia and Serbia, demonstrated constant rate of macroeconomic stability. Table 1 shows that IMS rate achieved by Ukraine in 2003 was the highest in comparison with other analyzed countries and was 41.36. At the same time, during the whole pre-crisis period (20002006) Belarus demonstrated the best dynamics of the macroeconomic stability (IMS indicator rate grew from 32.36 in 2000 to 45.39 in 2006). Therefore, as for macroeconomic stability, the best IMS indicator during the whole analyzed period was achieved by Belarus in 2006.

Observing the crisis phenomena intensity in 20072010 in terms of breaking the macroeconomic stability accepted range, one can see that economies in the studied countries can be divided into:

- countries, which are stable to crisis phenomena: Belarus;

- countries with moderate stability to crisis phenomena: Ukraine, Lithuania, Poland, Bulgaria, Georgia and Moldova;

- low stability countries to crisis: Latvia, Croatia, Romania, Armenia and Serbia.

Comparison of macroeconomic stability in European Union countries shows that economy in Latvia, Lithuania, Poland from the data of entry to European Union in 2004 became more stable. Such situation was observed till 2008; however, crisis in financial markets also had negative impact on economy stability in the analyzed countries. During 2011-2015 Romania, Poland, Lithuania essentially reduced a gap between IMS values, achieved in the pre-crisis period (2000-2006). This process was the fastest in Romania, economy of which can be characterized as a medium stable - 31.40. In spite of IMS indicator low rate in Croatia (in 2015 it was 19.59), economy of this country after the entry into the European Union in 2013 shows tendency of essential improvement of the macroeconomic stability.

The largest reduction of IMS in 2011-2015 was registered in Ukraine (17.97), Croatia (19.59), and Serbia (19.43).

Since 2006 the macroeconomic stability rate in Ukraine has worsened. Situation started to change in 20102012; however, after 2012 the macroeconomic stability worsened greately and reached its minimum rate in 2015 . Thus, comparing the macroeconomic stability in 20002006 with 2011-2015 one can see that the analyzed pentagon in 2015 reached the minimum value (Fig. 1).

The profiles of the mentioned countries are presented in Fig. 1.

The data from Table 2 proves the similarity of the macroeconomic stability trends for the analyzed countries. According to the received data the highest effects of macroeconomic stability trends are fixed between Lithuania and Latvia (0.89), Georgia and Latvia (0.88), Bulgaria and Croatia (0.8), Belarus and Croatia (0.86). It shows almost $90 \%$ coincidence of the economic development timing. Among the countries with the largest number of pair correlation positive coefficients, which exceeds 0.7, one can distinguish Armenia, Belarus, and Serbia. Negative values in the table show the inverse de- pendence, i.e. one country's upward trend is followed by downtrend of the other country.

The received results of the research on macroeconomic stability, shown in Fig. 2 for 2000-2015, demonstrated imbalance of pentagon surface forms. It proves the separate main macroeconomic indices growth with different rates. For example, the highest average growth of GDP in 2000-2015 was kept at the level of $6.92 \%$ of the annual growth, demonstrated by the Armenian economy. However, in spite of great increase in the mentioned index in 2003 to 14.04 , the total value of IMS was 25.10, that corresponds the medium stable economy. Among other EU countries this result strikes, but it is necessary to consider that it was achieved against high unemployment rate, which was more than 30\% during 2000-2005.

The lowest average growth of GDP in 2000-2015 was fixed in Croatia (1.68 \%), but it is necessary to point out positive increase in the GDP in 2015 againts the constant fall in 2009-2014 (approx. -7.4\% in 2009 and $-0.4 \%$ in 2014). Together with Croatia, Latvia and Lithuania had the biggest depression in the EU. Economy of Latvia decreased by $21 \%$ in 2008-2010, economy of Lithuania - by $12 \%$ in 2008-2009.

An average growth of the GDP in Ukraine over 2000-2015 was $4.03 \%$ of the annual growth. 2009 and 2010 were periods of GDP dynamics great decrease, appropriately by 14.33 and $3.78 \%$. Besides during the analyzed period one can distinguish years: 2005, 2006, 2007, when economy demonstrated the mentioned index growth at high rate $-10 \%$ per year.

It should be mentioned that as a result of the financial crisis, macroeconomic stability worsened in every analyzed aspect. High rate of unemployment (about 29\%) led to degradation of situation in Armenia, and high rate of the budget caused deficit as a percentage of the GDP $(-12 \%)$ and foreign deficit/debt (168\% GDP) in economy of Latvia. Ukraine had the highest index of inflation during 2007-2010 among the analyzed countries.

Analyzing the inflation increase rate in the Ukrainian economy, one can see that it is a significant problem, since its rate reached bivalent value in the analyzed period (in 2015 inflation rate grew to 48.72). Therefore, as it is mentioned in the research [11] one of the key factors which weaken an economic productive capacity of the country is inflation, which was supported by consumer's crediting extesion of economic entities. It does not match the macroeconomic level of the country's economy development.

Analyzing the data, demonstrated in diagram 2, it is reasonable to mention that low values of IMS indicator ratio to its subindices standard deviation sum show great risk to lose macroeconomic stability in the country and low synchronization of the regulatory policies concerning its main directions.

Thus, the given tendencies of the analyzed countries prove positive macroeconomic policy of the EU countries, which have high value of ratio between IMS indicator and its subindices standard deviation sum and is $0.51-1.23$. The studied index reached the maximum value twice during the analyzed period in Poland, particularly in 2007 and in 2015 its rate was 1.42 and 1.23 


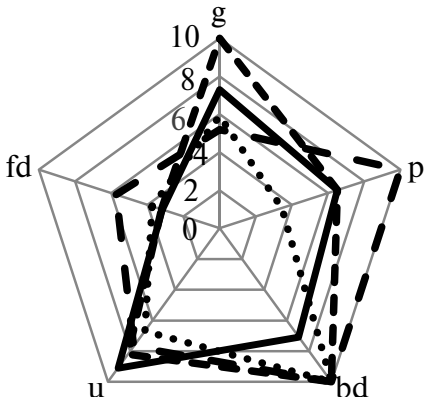

$2000-2002-02004-2006$

$a$

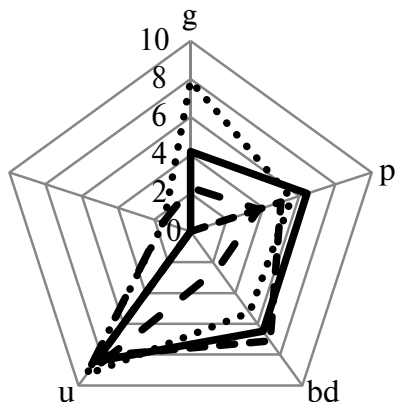

2007 - $2008-2009-2010$

$c$

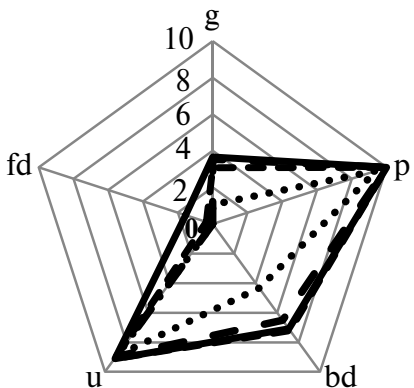

•....2011- - $2013-2015$
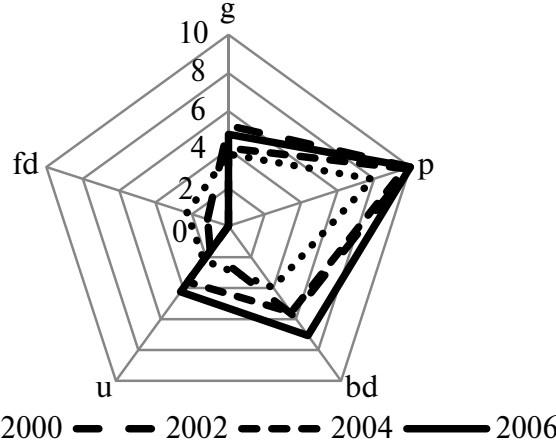

b

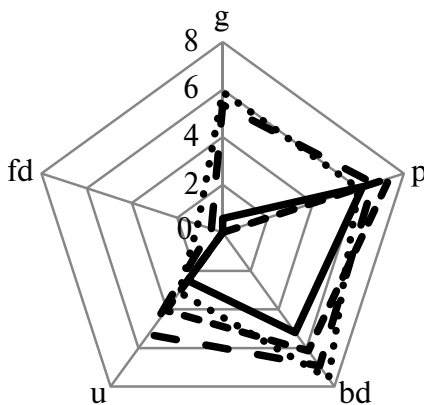

$2007-2008-2009$

$d$

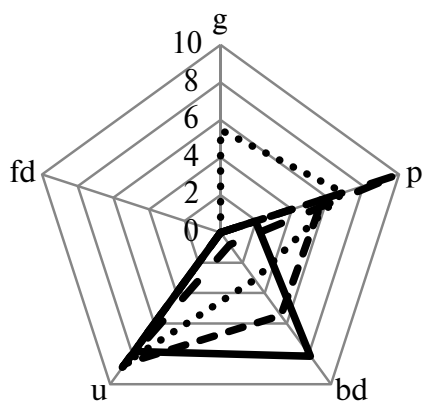

.....2011 - 2013 - 2015

$f$

Fig. 1. Comparison of IMS Profiles of certain countries (based on the authors' own calculations):

a-IMS Profile, Ukraine; $b$-IMS Profile, Croatia; c - IMS Profile, Belarus; d-IMS Profile, Serbia; e - IMS Profile, Romania;f-IMS Profile, Ukraine

Table 2

Matrix of IMS pair correlation coefficients for the lower-middle income economies countries for time period of 2000-2015 (the authors' own calculations based on Eurostat data) [1]

\begin{tabular}{|l|c|c|c|c|c|c|c|c|c|c|c|c|}
\hline & Ukraine & Latvia & Lithuania & Poland & Croatia & Romania & Bulgaria & Georgia & Moldova & Armenia & Belarus & Serbia \\
\hline Ukraine & 1.00 & & & & & & & & & & & \\
\hline Latvia & 0.55 & 1.00 & & & & & & & & & & \\
\hline Lithuania & $\mathbf{0 . 7 9}$ & $\mathbf{0 . 8 9}$ & 1.00 & & & & & & & & & \\
\hline Poland & -0.26 & 0.26 & 0.11 & 1.00 & & & & & & & & \\
\hline Croatia & 0.60 & 0.40 & 0.63 & 0.42 & 1.00 & & & & & & & \\
\hline Romania & 0.42 & $\mathbf{0 . 7 7}$ & $\mathbf{0 . 7 9}$ & 0.41 & 0.63 & 1.00 & & & & & & \\
\hline Bulgaria & 0.28 & 0.45 & 0.57 & 0.57 & $\mathbf{0 . 8 0}$ & $\mathbf{0 . 7 5}$ & 1.00 & & & & & \\
\hline Georgia & 0.52 & $\mathbf{0 . 8 8}$ & $\mathbf{0 . 7 8}$ & 0.26 & 0.37 & 0.64 & 0.44 & 1.00 & & & & \\
\hline Moldova & 0.33 & 0.20 & 0.32 & -0.31 & 0.17 & 0.37 & 0.15 & 0.25 & 1.00 & & & \\
\hline Armenia & 0.42 & $\mathbf{0 . 7 0}$ & 0.69 & 0.41 & 0.63 & $\mathbf{0 . 7 6}$ & 0.66 & $\mathbf{0 . 7 0}$ & 0.35 & 1.00 & & \\
\hline Belarus & 0.53 & 0.36 & 0.57 & 0.41 & $\mathbf{0 . 8 6}$ & 0.61 & $\mathbf{0 . 7 8}$ & 0.46 & 0.27 & $\mathbf{0 . 7 1}$ & 1.00 & \\
\hline Serbia & $\mathbf{0 . 7 2}$ & 0.45 & $\mathbf{0 . 7 1}$ & 0.09 & $\mathbf{0 . 8 0}$ & 0.68 & 0.59 & 0.23 & 0.35 & 0.51 & 0.65 & 1.00 \\
\hline
\end{tabular}



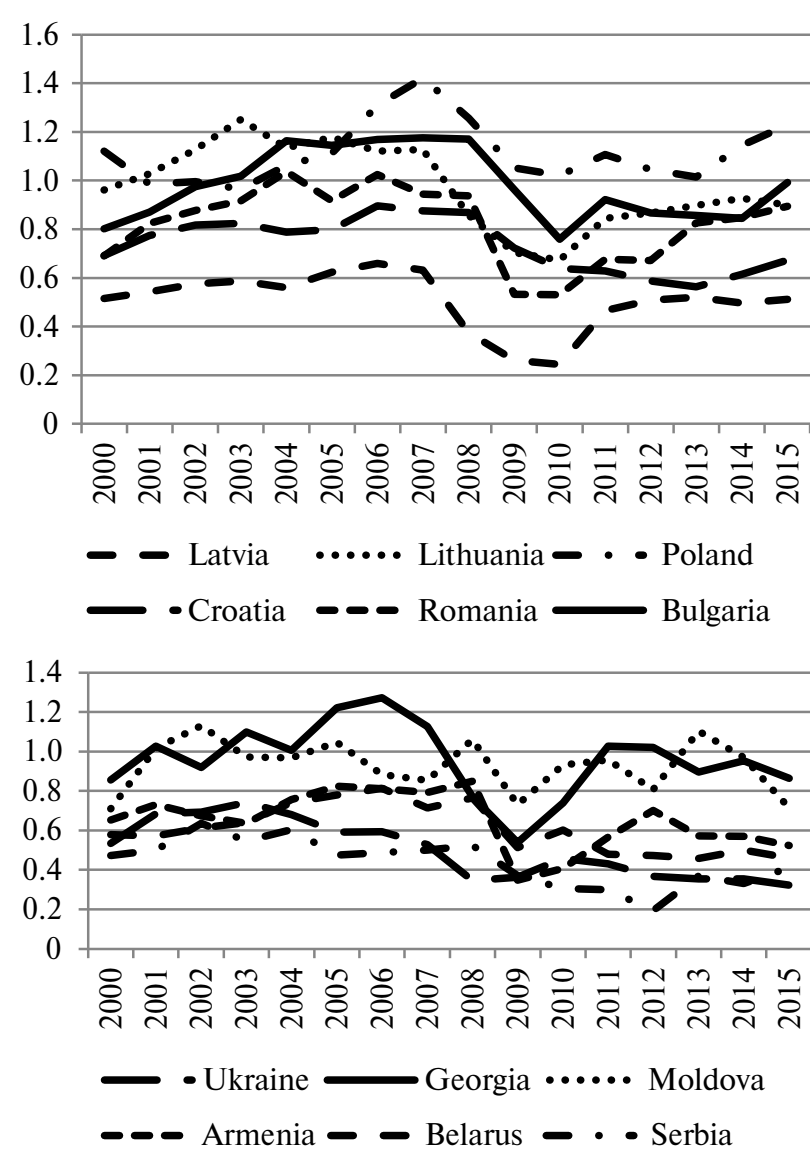

Fig. 2. Graphic interpretation of ratio of the IMS indicator to the sum of standard deviations of its components

correspondingly. Besides, it is reasonable to emphasize the right-handed asymmetry (Table 3 ) of every index in the macroeconomic stability in Poland, i.e., high probability of favorable deviations in the future.

As it is seen from the table above, two of five macroeconomic stability indices in Ukraine are divided with left-handed asymmetry: Real GDP growth (-1.05); Budget deficit (-0.26). However, the index of Real GDP growth has the biggest negative impact on the macroeconomic stability, because the asymmetry coefficient, which is less than 0.5 by module, is not taken into account [12]. At the same time, while forming the state policy concerning macroeconomic stability, it is necessary to pay attention to Inflation coefficient. Kurtosis Index for the mentioned coefficient is 5.43, and it proves the negative peak deviations around trend during the analyzed period.

Conclusions. Methods to evaluate macroeconomic stability, improved by us, were approbated for the lower-middle income economies of EU countries for the time period of 2000-2015. The results of the empiric analysis of macroeconomic stability pentagons for EU countries with the lower-middle-income economies at different stages of the economic cycle: pre-crisis period (2000-2006), crisis period (2007-2010) and post-crisis period (2011-2015) showed the lack of the appropriate coordination between certain types of the regulatory policies in the studied states to achieve macroeconomic stability high rate. For example, during the pre-crisis period most countries, except Croatia and Serbia, demonstrated stable rate of the macroeconomic stability; however, financial and economic crisis had negative impact on the economic stability of almost all analyzed countries. The largest reduction of IMS during 2011-2015 was registered in Ukraine (17.97), Croatia (19.59), and Serbia (19.43).

Together with statistic evaluation of the IMS indicator to consider standard deviations, asymmetry and extreme deviations of its component indexes allowed defining low synchronization of policies to provide the main directions of macroeconomic stability, in the analyzed countries. At the same time, it is necessary to point out positive tendency of EU countries, in which ratio of the IMS indicator to the standard deviations sum of its components is high enough compared to other analyzed countries and is located within the range of $0.51-1.23$. The

Table 3

Data on calculating Skewness and Kurtosis for the lower-middle income economy countries for time period of 2000-2015 (the authors' own calculations based on Eurostat data [1])

\begin{tabular}{|l|c|c|c|c|c|c|c|c|c|c|}
\hline \multirow{2}{*}{} & \multicolumn{2}{|c|}{$\begin{array}{c}\text { Real GDP growth } \\
(\%)\end{array}$} & \multicolumn{2}{c|}{$\begin{array}{c}\text { Inflation retail } \\
\text { prices (\%, a.a.) }\end{array}$} & \multicolumn{2}{c|}{$\begin{array}{c}\text { Budget deficit } \\
(\% \text { GDP) }\end{array}$} & \multicolumn{2}{|c|}{$\begin{array}{c}\text { Unemployment rate } \\
(\%)\end{array}$} & \multicolumn{2}{c|}{$\begin{array}{c}\text { Foreign debt } \\
\text { (\% GDP) }\end{array}$} \\
\cline { 2 - 13 } & Skewness & Kurtosis & Skewness & Kurtosis & Skewness & Kurtosis & Skewness & Kurtosis & Skewness & Kurtosis \\
\hline Ukraine & -1.05 & 3.27 & 1.58 & 5.43 & -0.26 & 2.05 & 0.69 & 2.71 & 0.98 & 3.73 \\
\hline Latvia & -1.38 & 4.66 & 0.97 & 3.22 & 1.70 & 4.75 & 0.20 & 2.41 & -0.18 & 1.70 \\
\hline Lithuania & -2.21 & 8.48 & 0.80 & 3.02 & 1.16 & 3.08 & -0.27 & 2.06 & -0.17 & 1.49 \\
\hline Poland & 0.25 & 2.41 & 0.71 & 3.72 & 0.25 & 2.14 & 0.36 & 1.45 & 0.12 & 1.39 \\
\hline Croatia & -0.98 & 3.40 & 0.21 & 2.57 & -0.38 & 2.20 & -0.26 & 2.43 & -0.27 & 1.73 \\
\hline Romania & 1.00 & 1.00 & -1.47 & 2.56 & -1.82 & 3.92 & -1.07 & 1.20 & -1.00 & 1.00 \\
\hline Bulgaria & -0.77 & 2.85 & 0.25 & 2.49 & -0.11 & 1.96 & 0.31 & 2.25 & -0.31 & 1.86 \\
\hline Georgia & -0.39 & 3.30 & 0.13 & 2.59 & 1.35 & 5.04 & 0.16 & 1.99 & -0.24 & 3.13 \\
\hline Moldova & -1.25 & 3.82 & 0.20 & 2.11 & 0.68 & 3.62 & -0.37 & 1.90 & 1.19 & 3.56 \\
\hline Armenia & -1.55 & 5.84 & -0.16 & 1.94 & 1.21 & 3.71 & 0.31 & 1.52 & -0.13 & 1.54 \\
\hline Belarus & -0.51 & 2.45 & 1.87 & 5.02 & 0.25 & 2.17 & 0.65 & 1.99 & 0.40 & 1.61 \\
\hline Serbia & -0.29 & 2.00 & 3.27 & 12.48 & 0.18 & 1.94 & -0.21 & 1.96 & -0.28 & 1.69 \\
\hline
\end{tabular}


studied index had maximum value twice during the analyzed period in Poland (in 2007 and 2015 its rate reached a grade of 1.42 and 1.23, accordingly). Besides, it is reasonable to emphasize the right-handed asymmetry (Table 3 ) of the macroeconomic stability of every indicator of Poland. It shows high probability of favorable deviations in the future.

Further research requires investigation of macroeconomic stability development plots in the analyzed countries considering optimal rate of the main IMS indicators through minimization of standard deviations gap, asymmetry and extreme deviations indicators.

This research was funded by the grant from the Ministry of Education and Science of Ukraine (№ g/r 0117 U003932).

\section{References.}

1. World Bank, 2017. World Development Indicators 2017, World Bank [online]. Available at: <https://data. worldbank.org/indicator $>$ [Accessed 30 June 2017].

2. WEF, 2017. The Global Comhetitiveness Report 20172018, 2009-2010, 2005-2006. World Economic Forum, Geneva [online]. Available at: <http//www.weforum.org > [Accessed 27 September 2017].

3. Malina, A. and Mierzwa, D., 2014. The Impact of the Global Crisis on the Macroeconomic Stability of the Countries of Central and Eastern Europe and Germany. In: Malina, A., Oczkowska, R. and Plichta, J., 2014. Knowledge - Economy - Society. Contemporary organizations in the process of institutional transformations. Foundation of the Cracow University of Economics. Kraków, pp. 13-24.

4. Hurduzeu, G. and Lazăr, M.-I., 2015. An Assessment of Economic Stability under the New European Economic Governance. Journal of Management Dynamics in the Knowledge Economy, 3(2), pp. 301-315.

5. Żuchowska, D., 2013. Assessment of the Central and Eastern Europe Economies in the Years 2007-2010 Based on the Model of the Macroeconomic Stabilization Pentagon, Equilibrium. Quarterly Journal of Economics and Economic Policy, 8(4), pp. 49-64.

6. Pera, J., 2016. Evaluation of the macroeconomic stability of central and eastern European countries with a view toward their membership in the European Union. Multidimensional risk analysis. Journal of Comparative Economic Research, 19(3), pp. 69-92.

7. Ionita, R.-O., 2015. The evolution of the macroeconomic stabilisation pentagon in Romania, Czech republic and Hungary. Journal of Annals of the University of Oradea: Economic Science, 25(1), pp. 733-741.

8. Lyulyuv, O. and Shvindina, H., 2017. Stabilization pentagon model: application in the management at macroand microlevels. Problems and Perspectives in Management, 15(3), pp. 42-52.

9. Zaman, C. and Drcelic, B., 2009. Macro-stabilisation issues in the Serbian Economy: Methodological Evaluation [online]. Available at: <http://ssrn.com/abstract= $1521660>$ [Accessed 1 November 2016].

10. Cariolle, J., 2012. Measuring macroeconomic volatility: applications to export revenue data, 1970-2005. Ferdi, Policy brief B47, March 2012 [online]. Available at: <http://www.ferdi.fr/sites/www.ferdi.fr/files/idi/I14 eng.pdf $>$ [Accessed 14 February 2017].

11. Vasilyeva, T.A., Leonov, S. V. and Lunyakov, O. V., 2013. Analysis of internal and external imbalances in the financial sector of Ukraine's economy, Journal of Actual problems of economics, 12, pp. 176-184.

12. Kolodiziev, O. M. and Maksimova, M. V., 2016. Improvement of diagnostic tools of financial controlling of banking operations. Scientific Journal, 6/1(23), pp. 25-33.

Мета. Розроблення методики оцінювання макроекономічної стабільності країн з низьким і середнім рівнем доходу. Результати аналізу допоможуть сформулювати висновки щодо впливу регуляторної економічної політики в даних країнах на рівень їх макроекономічної динаміки.

Методика. У роботі використана концепція п'ятикутника макроекономічної стабільності, в основу якої покладена оцінка п'яти базових макроекономічних показників: рівень зростання ВВП; рівень безробіття; рівень інфляції; сальдо бюджету держави до ВВП; сальдо величини поточних оборотів до ВВП. Застосований методичний інструментарій є модифікацією методики професора економіки Гжегожа В.Колодко, доктора Костянтина Замана та Бранко Дрцелича. Він доповнений пропозиціями авторів статті щодо врахування розриву середньоквадратичних відхилень, асиметрії та крайніх відхилень показників як динамічних індикаторів реакції економічних агентів на позитивні або негативні шоки макроекономічної дестабілізації.

Результати. Результати емпіричного аналізу п'ятикутників макроекономічної стабільності для країн 3 низьким і середнім рівнем доходу на різних стадіях економічного циклу (докризовий період (20002006 рр.), кризовий період (2007-2010 рр.) та посткризовий період (2011-2015 рр.)) засвідчили про відсутність належної координації різних типів економічної політики кожної з досліджуваних держав. Розраховано статичний індикатор макроекономічної стабільності. Запропоновано розраховувати динамічний індикатор, що відрізняється від статичного врахуванням середньоквадратичних відхилень, асиметрії та крайніх відхилень його субіндексів. Це дозволило відзначити низьку синхронізацію політик аналізованих країн, що мають забезпечувати основні п’ять напрямів макроекономічної стабільності.

Наукова новизна. Запропоновано поряд зі статичним індикатором макроекономічної стабільності розраховувати їі динамічний індикатор, що дозволяє:

- урахувати негативні тенденції, що можуть бути нівельовані за рахунок стабілізації всіх інших субіндексів;

- проаналізувати поведінку економічних агентів як реакцію на позитивні або негативні шоки;

- урахувати характер розподілу значень субіндексів інтегрального індикатору макроекономічної стабільності.

Практична значимість. Використання отриманих результатів дозволяє оцінити рівень координації окремих складових економічної політики досліджува- 
них держав з метою досягнення макроекономічної стабілізації. Це слугує підгрунтям для розробки сценаріїв досягнення макроекономічної стабільності 3 урахуванням оптимального рівня основних субіндексів інтегрального індикатора макроекономічної стабільності, мінімізації розриву середньоквадратичних відхилень, асиметрії та крайніх відхилень показників.

Ключові слова: макроекономічна стабільність, економічне зростання, конкурентоспроможність, економічна політика, макроекономічні дисбаланси, кризові явища

Цель. Разработка методики оценки макроэкономической стабильности стран с низким и средним уровнем дохода. Результаты анализа помогут сформулировать выводы о влиянии регуляторной экономической политики в этих странах на уровень их макроэкономической динамики.

Методика. В работе использована концепция пятиугольника макроэкономической стабильности, в основу которой положена оценка пяти базовых макроэкономических показателей: уровень роста ВВП; уровень безработицы; уровень инфляции; сальдо бюджета государства в ВВП; сальдо величины текущих оборотов в ВВП. Примененный методический инструментарий является модификацией методики профессора экономики Гжегожа В. Колодко, доктора Константина Замана и Бранко Дрцелича. Он дополнен предложениями авторов статьи по учету разрыва среднеквадратических отклонений, асимметрии и крайних отклонений показателей как динамических индикаторов реакции экономических агентов на положительные или отрицательные шоки макроэкономической дестабилизации.

Результаты. Результаты эмпирического анализа пятиугольников макроэкономической стабильности для стран с низким и средним уровнем дохода на разных стадиях экономического цикла (докризисный период (2000-2006 гг.), кризисный период (2007-2010 гг.) и посткризисный период (20112015 гг.)) засвидетельствовали отсутствие должной координации различных типов экономической политики каждой из исследуемых стран. Рассчитан статический индикатор макроэкономической стабильности. Предложено рассчитывать динамический индикатор, который отличается от статического учетом среднеквадратических отклонений, асимметрии и крайних отклонений его субиндексов. Это позволило отметить низкую синхронизацию политик анализируемых стран, которые должны обеспечивать основные пять направлений макроэкономической стабильности.

Научная новизна. Предложено наряду со статическим индикатором макроэкономической стабильности рассчитывать ее динамический индикатор, который позволяет:

- учесть негативные тенденции, которые могут быть нивелированы за счет стабилизации всех остальных субиндексов;

- проанализировать поведение экономических агентов как реакцию на положительные или отрицательные шоки;

- учесть характер распределения значений субиндексов интегрального индикатора макроэкономической стабильности.

Практическая значимость. Использование полученных результатов позволяет оценить уровень координации отдельных составляющих экономической политики исследуемых стран с целью достижения макроэкономической стабильности. Это служит основой для разработки сценариев достижения макроэкономической стабильности с учетом оптимального уровня основных субиндексов интегрального индикатора макроэкономической стабильности, минимизации разрыва среднеквадратических отклонений, асимметрии и крайних отклонений показателей.

Ключевые слова: макроэкономическая стабильность, экономический рост, конкурентоспособность, экономическая политика, макроэкономические дисбалансы, кризисные явления

Рекомендовано до публікації докт. екон. наук О.В. Кузьменко. Дата надходження рукопису 04.12.16. 